\title{
New data on the genus Albinaria Vest, 1867 (Pulmonata Clausiliidae) from the Astypalea Island and neighboring islets (Dodecanese Archipelago, Greece)
}

\author{
Fabio Liberto ${ }^{*}$, Maria Stella Colomba ${ }^{2} \&$ Ignazio Sparacio ${ }^{3}$ \\ ${ }^{1}$ Via del Giubileo Magno 93, 90015 Cefalù, Italy; e-mail: fabioliberto@ yahoo.it \\ ${ }^{2}$ Università di Urbino, Department of Biomolecular Sciences, via Maggetti 22, Urbino, Italy; e-mail: mariastella.colomba@ \\ uniurb.it \\ ${ }^{3}$ Via Principe di Paternò 3, 90144 Palermo, Italy; e-mail: edizionidanaus@ gmail.com \\ *Corresponding author
}

\begin{abstract}
In this work, the authors investigated the genus Albinaria Vest, 1867 (Pulmonata Clausiliidae) from the Astypalea Island and the nearby islets of Ofidoussa and Kounoupi (Dodecanese Archipelago, Greece). The two endemic subspecies known, Albinaria (Albinaria) brevicollis astropalia (O. Boettger, 1883) and A. (A.) brevicollis maltezana Nordsieck, 2015 are redescribed and illustrated for shell and genital morphology. Furthermore A. (A.) brevicollis cf. sica Fuchs et Käufel, 1936 is reported for the first time from the north-east Astypalea, and two new subspecies, $A$. (A.) brevicollis granoi $\mathrm{n}$. ssp. and $A$. (A.) brevicollis cristinae $\mathrm{n}$. ssp. are here described from NorthWest Astypalea and Ofidoussa Islet, respectively.
\end{abstract}

KEY WORDS

Taxonomy; morphology; new subspecies; distribution.

Received 26.07.2018; accepted 03.10.2018; published online 28.12.2019

Proceedings of the 4th International Congress on Biodiversity "Man, Natural Habitats and Euro-Mediterranean Biodiversity", November 17th-19th, 2017 - Malta

\section{INTRODUCTION}

The highly diverse genus Albinaria Vest, 1867 (Pulmonata Clausiliidae) is present in the Dodecanese Archipelago (South-East Aegean region) with 12 species and 34 subspecies (Bank, 2017, 2019). The species identification is almost exclusively based on shell morphology and recent molecular studies have mainly confirmed species classification based on shell morphology (Douris et al., 2007).

In the Dodecanese Archipelago, A. (Albinaria) brevicollis (L. Pfeiffer, 1850) is the most diversified species with 17 subspecies.

In the Astypalea Island, two endemic subspecies of A. (A.) brevicollis are known: Albinaria brevi- collis astropalia (O. Boettger, 1883) from the western part of the island (Kora and Livadhi nearby) and A. brevicollis maltezana (Nordsieck, 2015) known only from the type locality, mountain ridge NorthEast Maltezana = Analipsi (Fuchs \& Käufel, 1936; K.L. Pfeiffer, 1955; Nordsieck, 2015).

In 2015, Mauro Grano and Cristina Cattaneo (Rome, Italy), during a naturalistic trip, have sampled fifteen populations of Albinaria on the Astypalea Island and on the nearby islets of Ofidoussa and Kounoupi.

The examination of this material revealed the presence of five different populations of A. (A.) brevicollis; two correspond to the known endemic subspecies A. (A.) brevicollis astropalia and A. (A.) brevicollis maltezana respectively, the other three 
are new to the island group of Astypalea and are discussed below.

\section{MATERIAL AND METHODS}

\section{Study area}

The island group of Astypalea (Dodecanese Archipelago, Greece) lies in the South-East Aegean Sea, representing a transition zone between the Kiklades islands and the eastern Aegean (Fig. 1). Astypalea is the largest island of the group, with an area of $96 \mathrm{~km}^{2}$. It consists of two parts: a western half (Exo Nisi) and an eastern one (Mesa Nisi), joined by a narrow isthmus (Steno), $105 \mathrm{~m}$ wide, derived from the collapse of the neighboring territories. The two extreme parts of the island consist mainly of limestone, while the central part is flysch and alluvial (Fig. 2). The highest relief is Vardhia (482 m). Maquis and phrygana constitute the dominant vegetation types with different endemic or rare animal and plant taxa. Astypalea is surrounded by numerous smaller uninhabited off-shore islets, the largest of which are Kounoupi to the southeast and Ofidoussa to the west. Both consist mainly of limestone (Fig. 3).

\section{Sampling methods}

All samples examined for this paper were collected by M. Grano and C. Cattaneo, from 2nd August to 18th August 2015 and from 24th April 2016 to 26th April 2016. The names of local places mentioned in the text and in the map (Fig. 1) follow the map of Astypalea produced by Terrain Cartography Group (2009). Specimens were collected chronologically from the following localities:

Astypalea, Livadhi, $36^{\circ} 32^{\prime} 58^{\prime \prime} \mathrm{N}-26^{\circ} 19^{\prime} 59^{\prime \prime} \mathrm{E}, 51$ m, 02.VIII.2015

Astypalea, Vardhia, 36 31'29'” - 26'19'11'”E, $375 \mathrm{~m}, 03$. VIII.2015

Astypalea, Vatses, $36^{\circ} 30^{\prime} 53^{\prime \prime} \mathrm{N}-26^{\circ} 19^{\prime} 13^{\prime \prime} \mathrm{E}, 80$ m, 04.VIII.2015

Astypalea, Aghios Konstantinos, 36³1'39' N 26²1'15'”, 10 m, 06.VIII.2015

Astypalea, Kaminakia, $36^{\circ} 31^{\prime} 19^{\prime \prime} \mathrm{N}-26^{\circ} 18^{\prime} 14$ ' E, $42 \mathrm{~m}, 07$. VIII. 2015

Kounoupi Islet, $36^{\circ} 32^{\prime} 07^{\prime \prime} \mathrm{N}-26^{\circ} 28^{\prime} 04^{\prime \prime} \mathrm{E}, 50 \mathrm{~m}$, 10-11.VIII.2015
Astypalea, Dhracospilia $36^{\circ} 38^{\prime} 21^{\prime \prime} \mathrm{N}-26^{\circ} 22^{\prime} 50^{\prime \prime} \mathrm{E}$, $54 \mathrm{~m}, 13$. VIII. 2015

Astypalea, Panormos, $36^{\circ} 35^{\prime} 10^{\prime \prime} \mathrm{N}-26^{\circ} 16^{\prime} 37^{\prime \prime} \mathrm{E}$, $16 \mathrm{~m}$, 14.VIII.2015

Astypalea, Pachia Ammos, 36 35'31' N 26'17'30'”, $41 \mathrm{~m}, 15$.VIII.2015

Ofidoussa Islet, $36^{\circ} 33^{\prime} 12^{\prime}$ N $-26^{\circ} 08^{\prime} 23^{\prime \prime} \mathrm{E}, 82 \mathrm{~m}$, 18.VIII.2015

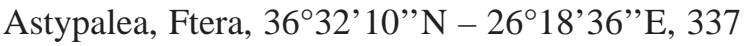
m, 18.VIII.2015

Astypalea, Ftera, 36 33'21'”N - 26 $6^{\circ} 7^{\prime} 12^{\prime \prime \prime} \mathrm{E}, 326$ m, 24.IV.2016

Astypalea, Vatses, $36^{\circ} 30^{\prime} 58^{\prime \prime \prime} \mathrm{N}-26^{\circ} 19^{\prime} 25^{\prime \prime \prime} \mathrm{E}, 186$ m, 25.IV.2016

Astypalea, Koutela, $36^{\circ} 31^{\prime} 38^{\prime \prime} \mathrm{N}-26^{\circ} 18^{\prime} 57^{\prime \prime} \mathrm{E}$, 393 m, 26.IV.2016

Astypalea, Kora, $36^{\circ} 32^{\prime} 36^{\prime \prime} \mathrm{N}-26^{\circ} 20^{\prime} 49^{\prime \prime} \mathrm{E}, 43 \mathrm{~m}$, 26.IV.2016

The land snails were collected by hand on the soil and on the rocks. Dry shells have been studied as regards size, sculpture, aperture, plicae and lamellae, lunella and clausilium. In order to study and illustrate genital organs, the specimens were drowned in water and fixed in $75 \%$ ethanol. Reproductive apparatus was extracted by means of scalpel, scissors and needles. Height and maximum diameter of the shell along with some parts of genitalia were measured (in millimeters) with a digital gauge. Photographs were taken with a digital camera. Taxonomical references are based on the checklist of the land and freshwater Gastropoda of Europe (Bank, 2017, 2019). The voucher specimens are deposited in the following Museums and private collections: CG (M. Grano collection, Roma, Italy), CL (F. Liberto collection, Cefalù, Italy), MCZR (Museo Civico di Zoologia, Roma, Italy), CP (G. Pocaterra collection, San Pietro in Casale, Italy), CS (I. Sparacio collection, Palermo, Italy).

ABBREVIATIONS AND ACRONYMS. D: shell diameter, H: shell height, ex: specimen, exx: specimens, R2: ribs number on $2 \mathrm{~mm}$ of the penultimate whorl, sh/s: shell/s.

ANATOMICAL ACRONYMS. AG: albumen gland, BC: bursa copulatrix, BCD: diverticulum of bursa copulatrix, CD: copulatory duct, DBC: duct of bursa copulatrix, E: epiphallus, FO: free oviduct, GA: genital atrium, HD: hermaphrodite duct, O: ovotestis, OV: ovispermiduct, P: penis, PC: penial 


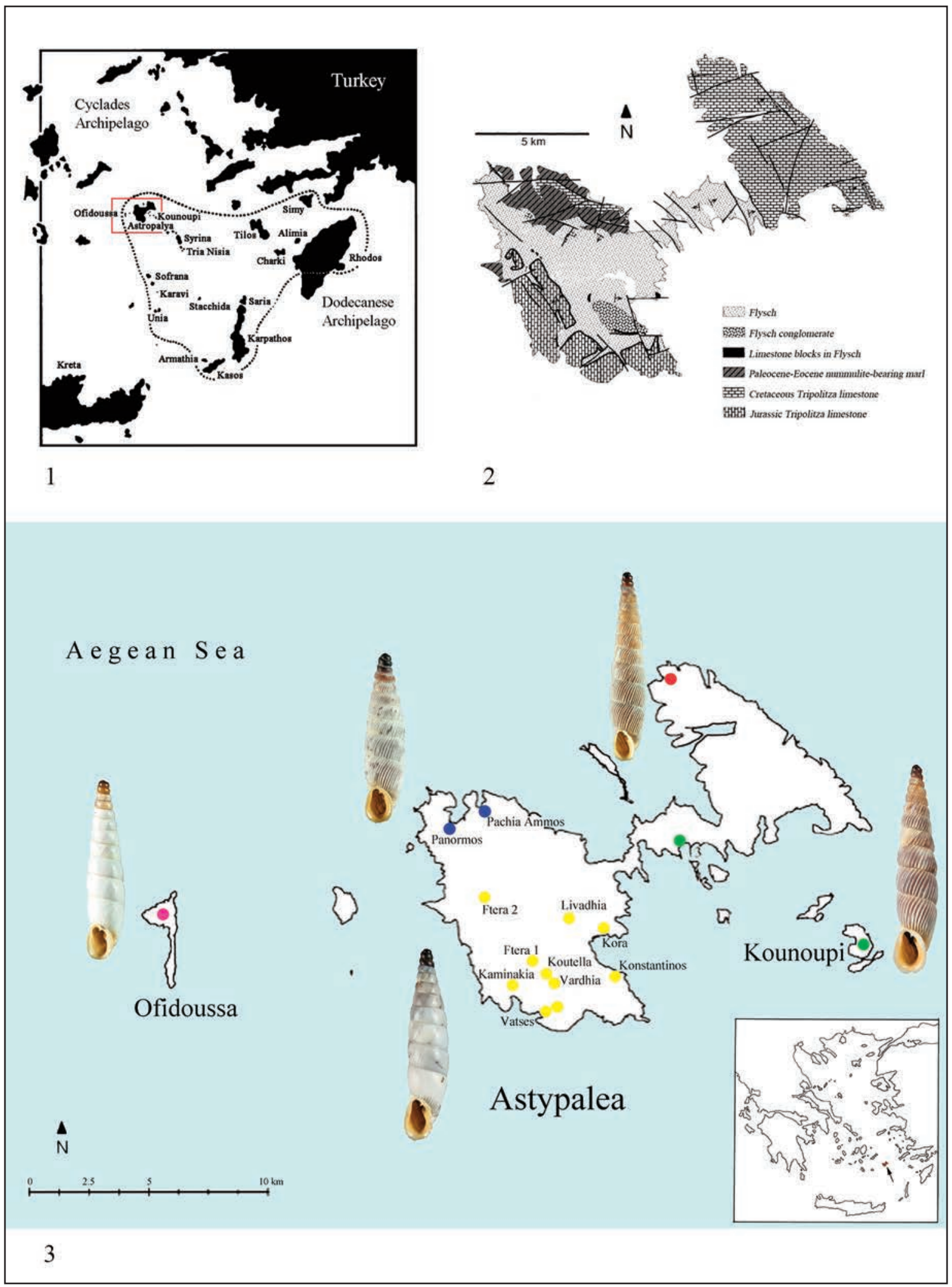

Figure 1. Map of Dodecanese Archipelago. Figure 2. Geological map of Astypalea Island (modified from Ring, 2001). Figure 3. Distribution map of the subspecies of Albinaria brevicollis in the island group of Astypalea; yellow dots: A. b. astropalia, green dots: A. b. maltezana, red dot: A. b. cf. sica, blue dots: A. b. granoi n. ssp, purple dot: A. b. cristinae n. ssp. 
caecum, PR: penial retractor muscle, V: vagina, VD: vas deferens, VP: V-shaped pleat.

CONCHOLOGICAL ACRONYMS. B: basal plica (= lower palatal plica), IL: inferior lamella, L: lunella, PP: principal plica, PUPP: posterior upper palatal plica, UL: upper lamella, SCL: subcolumellar lamella, SL: spiral lamella, SS: subclaustralis.

\section{RESULTS}

\section{Systematics}

Classis GASTROPODA Cuvier, 1795 Ordo STYLOMMATOPHORA Schmidt, 1855 Familia CLAUSILIIDAE Gray, 1855 Subfamily ALOPIINAE A.J. Wagner, 1913 Tribe MEDORINI H. Nordsieck, 1997 Genus Albinaria Vest, 1867

Subgenus Albinaria Vest, 1867

\section{Albinaria (Albinaria) brevicollis astropalia (O. Boettger, 1883)}

EXAMINED MATERIAL. Greece, Southwest Astypalea Island, Livadhi, $36^{\circ} 32^{\prime} 58.11^{\prime \prime} \mathrm{N} 26^{\circ} 19^{\prime} 59.64$ " E, $51 \mathrm{~m}, 02 . V I I I .2015,2$ exx, 4 shs (CL 158163; Figs. 14-15 genitalia CL 158); idem, Ftera, 36 32'10.95' $\mathrm{N} \quad 26^{\circ} 18^{\prime} 36.79$ ' $\mathrm{E}, 337 \mathrm{~m}$, 18.VIII.2015, 6 exx. (CL 164-169); idem, Vardhia, 36 31'29.48'N 26¹9'11.50”'E, 375 m, 03.VIII.2015, 5 exx, 3 shs (CL 170-177; Fig. 7 parietum CL 171); idem Vatses, 36 30'53.86'"N 2619'13.46”'E, 80 m, 04.VIII.2015, 6 exx, 2 shs, (CL 178-185; Fig. 6 parietum CL 178); idem, Aghios Konstantinos, 36 31'39.53”N 26²1'15.53”E, 10 m, 06.VIII.2015, 5 exx, 4 shs (CL 187-195; Fig. 5 shell CL 195; Fig. 8 palatum CL 187; Fig. 13 genitalia (CL 188.); idem, Kaminakia, 36 31'19.32'”N 2618'14.98”'E, 42 m, 07.VIII.2015, 7 exx, (CL 196-202); idem, 2 exx (CS); idem, Kora, 36 32'36'N 26²0'49'”, 43 m, 26.IV.2016, 1 ex, 6 shs, (CL373-379); idem, Ftera, 36³3'21,45'N 2617'39,12'”, 326 m, 24.IV.2016, 7 exx, 2 shs, (CL 381-389; Fig. 4 shell CL 388; Fig. 10 clausilium CL 382; Figs. 11-12 genitalia CL 381); idem, Vatses, $36^{\circ} 30^{\prime} 58,67^{\prime \prime} \mathrm{N} 26^{\circ} 19^{\prime} 25,63$ '"E, 186 m, 25.IV.2016, 7 exx, (CL 399-405); idem, Koutela, 36³1'38,68”N 2618'57,62”'E, 393 m, 26.IV.2016, 9 exx, 1 sh, (CL 411-424; Fig. 9 palatum CL 420).
DESCRIPTION. Fusiform shell more or less slender, white bluish in color, with smooth whorls, some ribs are present only on the last half of the last whorl, almost absent dorsal keel (Figs. 4, 5); principal plica well developed, posterior upper palatal plica fused with lunella apex; lunella dorsolateral, in part with basalis rudiment (Figs. 6, 7); superior lamella reaching spiral lamella.

Genitalia typical of $A$. (A.) brevicollis with a well developed cylindrical or conical penial caecum (1-2.6 mm, mean $1.6 \mathrm{~mm}$ ) a V-shaped crest inside the penis (Figs. 11-15).

Measurements of the shell: H: $13.7-19.7 \mathrm{~mm}$, (mean: $16 \mathrm{~mm}$ ), D: 3-4.16 mm (mean: $3.6 \mathrm{~mm}$ ), whorls: 9-11.75 (mean: 10.5).

Distribution. The type of A. (A.) brevicollis astropalia comes from Kora (West Astypalea). Nordsieck (2015) ascribes also the population from Livadhi locality. Based on our sampling A. (A.) brevicollis astropalia is also present in Ftera, Vardhia, Koutela, Vatses and Aghios Konstantinos locality (South-West Astypalea).

REMARKs. The populations of Konstantinos, with $\mathrm{H}: 14.46, \mathrm{D}: 3.2$ and 10 whorls, is the smallest population of A. (A.) brevicollis astropalia.

\section{Albinaria (Albinaria) brevicollis maltezana \\ Nordsieck, 2015}

EXAMINED MATERIAL. Kounoupi Islet, southeast Astypalea Island, Greece, $36^{\circ} 32^{\prime} 07.48^{\prime}$ 'N 26⒉ $8^{\prime} 04.88^{\prime \prime}$ 'E, 50 m, 10-11.VIII.2015, 10 exx, 4 shs (CL 316-331; Figs. 16-17 shells CL 326-327; Figs. 18-19 parietum CL 318-319; Figs. 20-21 palatum CL 330-331; Figs. 22, 23 clausilium Cl 330, 320; Figs. 24-27 genitalia CL 316-317; idem 2 exx (CS).

DESCRIPTION. Shell distinctly ribbed, dorsal keel mostly prominent; superior lamella often reaching or surpassing spiral lamella, means dimensions $\mathrm{H}$ : $16.3 \mathrm{~mm}, \mathrm{D}: 3.4 \mathrm{~mm}, \mathrm{R} 2(\mathrm{n}=11)$ : 8-12 (mean 9.9).

Dimension of genitalia (means of two specimens examined): P: $2.6 \mathrm{~mm}$, E: $3.9 \mathrm{~mm}, \mathrm{PC}: 2.25$ $\mathrm{mm}$; vagina: $4.6 \mathrm{~mm}, \mathrm{CD} 1.4 \mathrm{~mm}, \mathrm{DBC}+\mathrm{BC} 3.3$ $\mathrm{mm}$, BCD: $7 \mathrm{~mm}$.

DistRIBUTION. Albinaria (A.) brevicollis maltezana is known only for the type locality: mountain ridge North East Maltezana = Analipsi (Nordsieck, 2015). 
REMARKS. We ascribe to this subspecies the population of the small islet of Kounoupi ( $8 \mathrm{~km}$ South-East of Maltezana), which shows the same mean dimensions and the same distinctive characters in the shell (Figs. 16-23). We observed some specimens with the lower part of the lunella bent inwards $=$ rudiment subclaustralis (Fig. 19). We examined the genitalia of two specimens. They show a very long vagina of $6 \mathrm{~mm}$ and $4.35 \mathrm{~mm}$ respectively, and diverticulum of the bursa copulatrix of $9 \mathrm{~mm}$ and $7 \mathrm{~mm}$, respectively. However, this may be due to a recent mating, as evidenced by the presence of the spermathophora inside the diverticulum (Figs. 24-27). We have also sampled on the small islet of Koutsomiti, but here we have not found $\mathrm{Al}$ binaria.

\section{Albinaria (Albinaria) brevicollis cf. sica Fuchs et Käufel, 1936}

EXAmined Material. Astypalea, Dhracospilia, near the cave Dhracospilia, Northeast Astypalea,

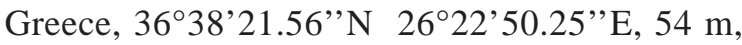
13.VIII.2015, 8 exx, 6 sh (CL 214-224; Figs. 2829 shells CL 214, 224; Figs. 30-31 parietum CL 215-216; Figs. 32-33 palatum CL 225-226; Fig. 34 clausilium CL 225; Figs. 35-36 genitalia CL 215; Figs. 37-38 genitalia CL 216); idem 2 exx (CS).

DESCRIPTION. Slender conical shell; 1.5-2 apical whorls convex and brown; the other whorls convex, uniformly ribbed, brown in colour with white ribs; irregular ribs on the last part of the last whorl; dorsal keel low or moderately high; peristome oval detached (Figs. 28-29); lower part of lunella with a rudiment basalis or bent inwards = rudiment subclaustralis (Figs. 30-31), upper lamella rarely reaches the spiral lamella (Figs. 3233, 35-38).

Dimensions of the shell: $\mathrm{H}: 13.7-16.5 \mathrm{~mm}$, (mean $15.5 \mathrm{~mm}$ ), D: $2.8-3.3 \mathrm{~mm}$ (mean $3.2 \mathrm{~mm}$ ), whorls: 10-12.5 (mean 11.3), R2 ( $=9$ ): 9-15 (mean 11.5).

Dimensions of the genitalia (two specimens examined): P: $1.5-2.4 \mathrm{~mm}, \mathrm{E}: 2-3.15 \mathrm{~mm}, \mathrm{PA}: 0.7-$ $2 \mathrm{~mm}$; V: $1.5-3.4 \mathrm{~mm}, \mathrm{CD} 1-1.1 \mathrm{~mm}, \mathrm{DBC}+\mathrm{BC}$ 1-2 mm, BCD: $2.9-4.7 \mathrm{~mm}$

REMARKs. The Albinaria population of Dhra- cospilia is very similar to $A$. (A.) brevicollis sica described for the island of Megali Zafora, the largest and northernmost of the Zafora islands (about 50 $\mathrm{km}$ southeast of Astypalea). We attribute the Dhracospilia population to this subspecies, but further sampling and examination are desiderable to clarify the philogenetic relations both with $A$. (A.) brevicollis sica from the type locality both with $A$. (A.) brevicollis maltezana.

Albinaria (Albinaria) brevicollis granoi $\mathrm{n}$. ssp.

TyPe LOCAlity. Pachia Ammos, North-West Astypalea Island, Dodecanese Archipelago, Greece.

TyPe Material. Holotype (Fig. 39): Pachia Ammos, on the rocks close to the sea, North-West Astypalea Island, $36^{\circ} 35^{\prime} 31.15^{\prime \prime} \mathrm{N} 26^{\circ} 17^{\prime} 30.12^{\prime \prime} \mathrm{E}$, $41 \mathrm{~m}$, M. Grano and C. Cattaneo legit, 15.VIII.2015, (MCZR-M-TYPE 00250/H). Paratypes: idem 8 exx., 11 shs, (CL 240-258; Fig. 40 shells CL 249; Figs. 41-42 parietum CL 241, 251; Figs. 43-44 palatum CL 250, 251; Figs. 45-46 clausilium CL 242, 251; Figs. 47-48 genitalia CL 240; Figs. 49-50 genitalia CL 241); idem 2 shs (CS); idem 2 shs (CG); Panormos, on the rocks close to the sea, North-West Astypalea Island, $36^{\circ} 35^{\prime} 10.26^{\prime \prime} \mathrm{N} 26^{\circ} 16^{\prime} 37.62^{\prime \prime} \mathrm{E}$, 16 m, 14.VIII.2015, 1 ex, 5 shs (CL 230-235); idem 2 shs $(\mathrm{CP})$.

DIAGNOSIS. Spindle-shaped, medium-small shell H: 13.9, D: 2.9, with 10.5 whorls (mean of 15 shells), characterized by rounded apical and subapical whorls, spire ribbed, basal keel and dorsal keel distinct, upper lamella reaches or does not reach spiral lamella.

DESCRIPTION OF THE HOLOTYPE (Fig. 39). Spindle-shaped shell, H: $12.9 \mathrm{~mm}$, D: $2.9 \mathrm{~mm}$; with $10 \frac{1}{2}$ whorls, the apical and subapical whorls are more convex than the subsequent ones, the two apical whorls are dark brown, the following white with ample brown spots and points and with uniformly white ribs, R2: 14; on the last part of the last whorl the ribs are irregular; sutural bulge present, basal keel distinct, dorsal keel about as high as basal keel and shorter, detached oval peristome; upper lamella reaching the spiral lamella; inferior lamella low within, ending on columellar edge in front; lower part of lunella with a rudiment of basalis. 


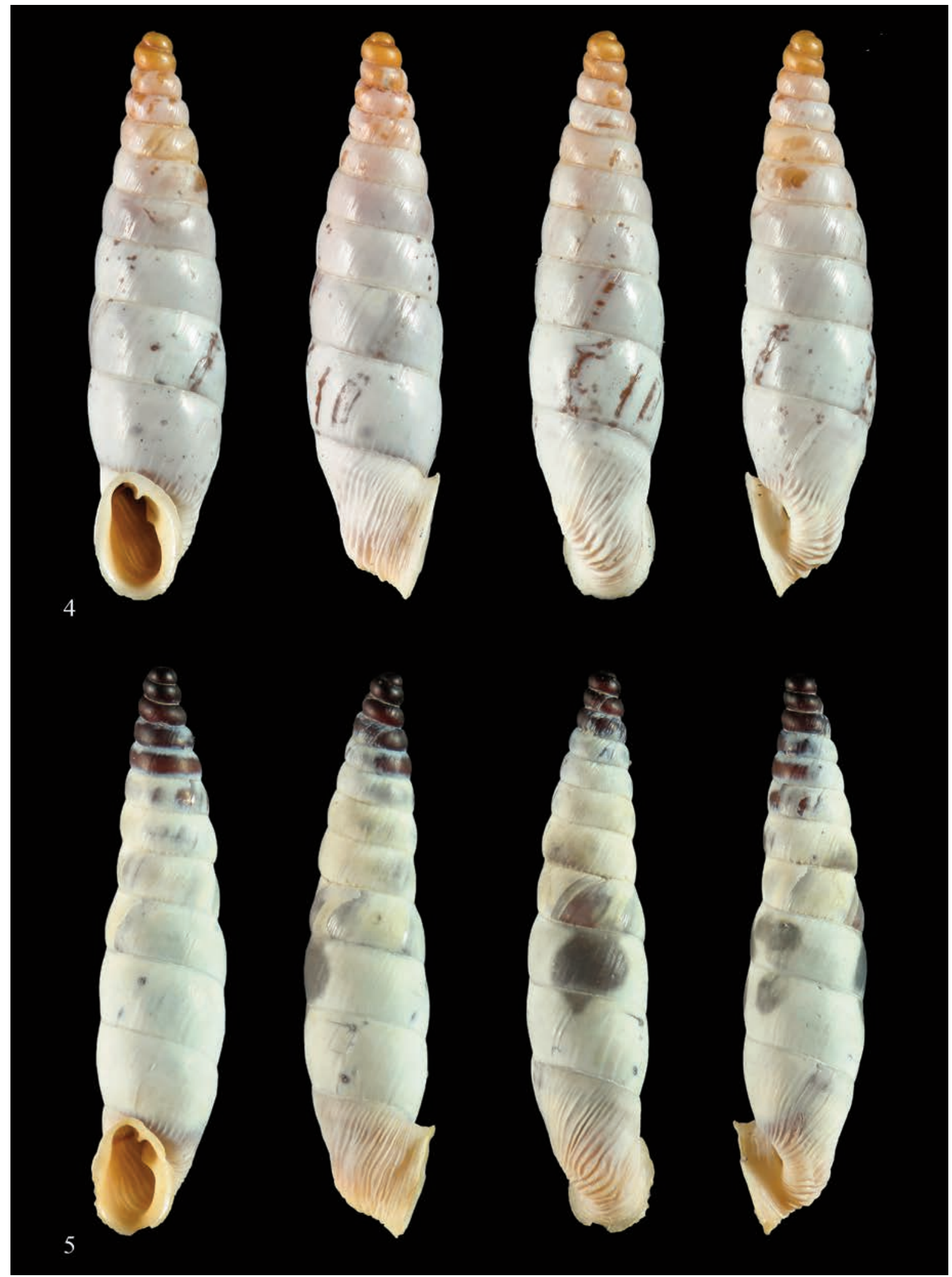

Figure 4. Shell of Albinaria (Albinaria) brevicollis astropalia Ftera, Astypalea Island, Greece, H: 15.1 mm, D: 3.6 mm. Figure 5. Idem, Aghios Konstantinos, Astypalea Island, Greece, H: 15.2 mm, D: 3.3 mm. 


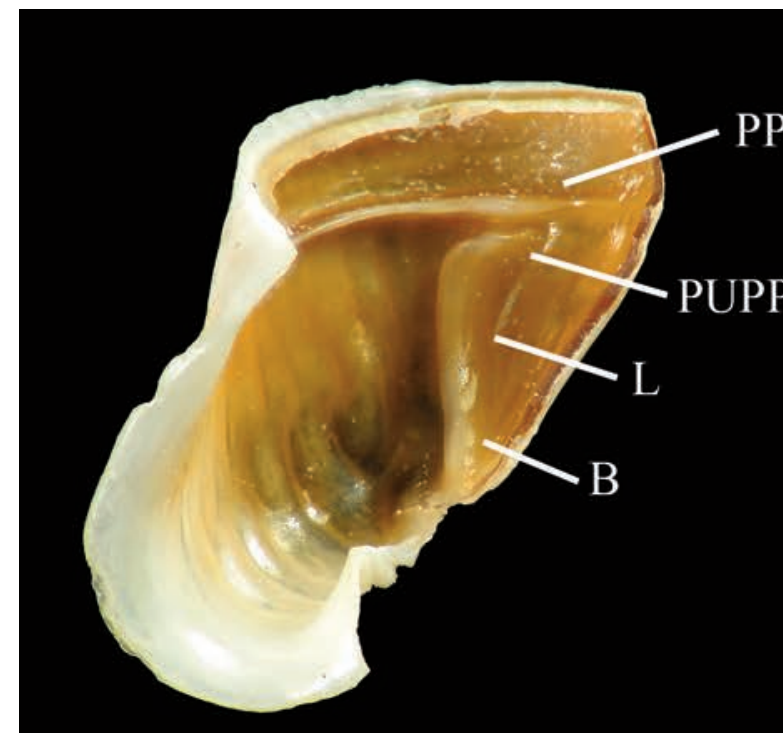

6

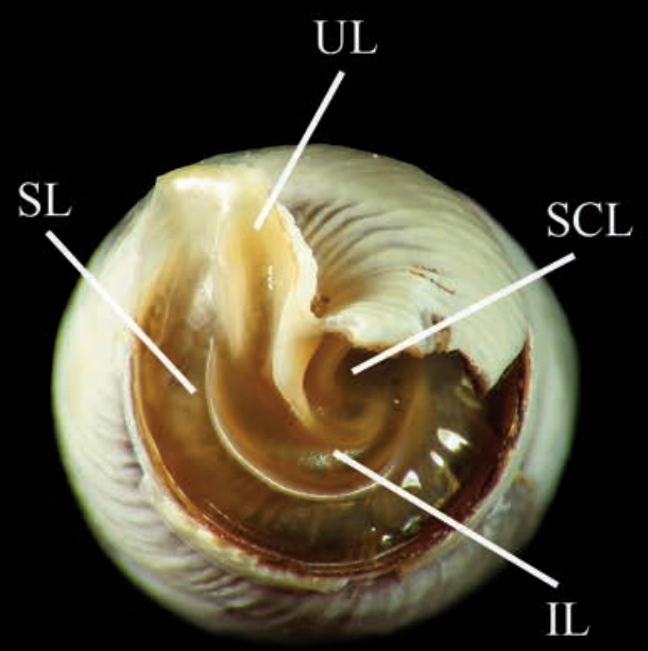

8

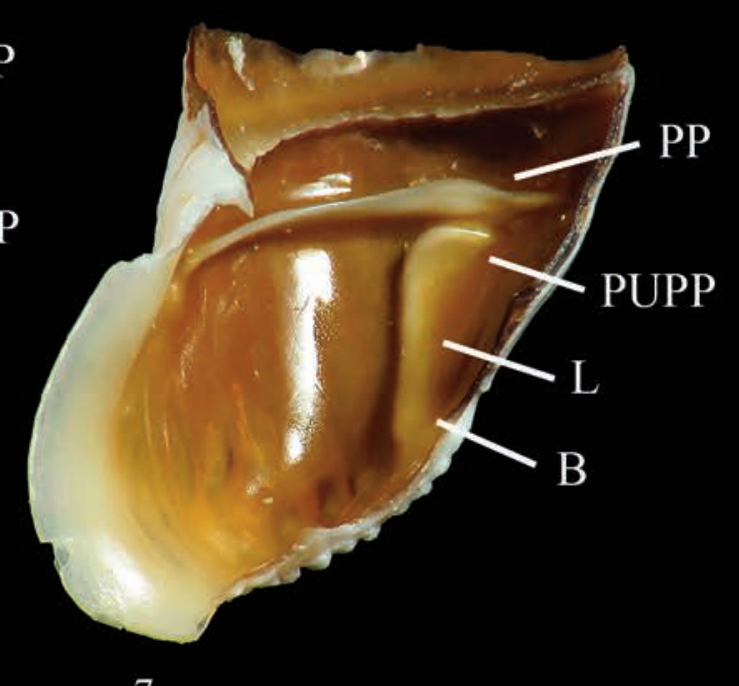

7

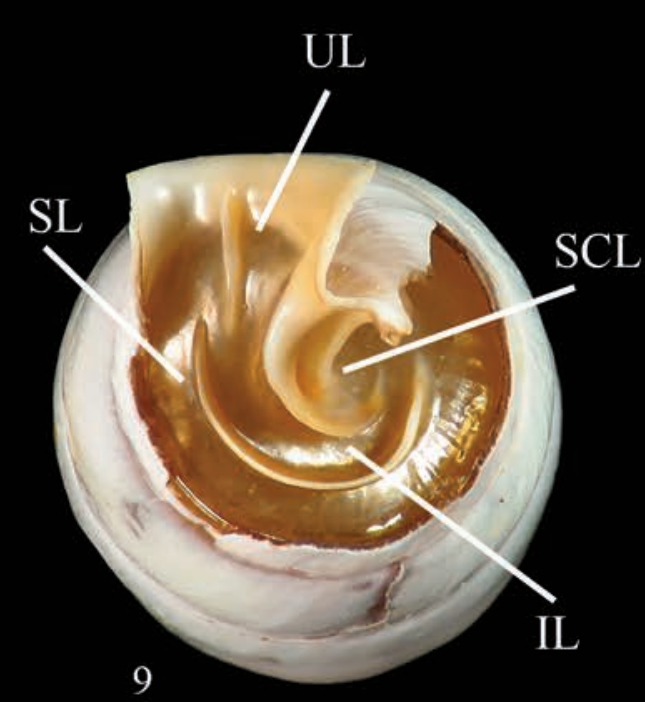

10

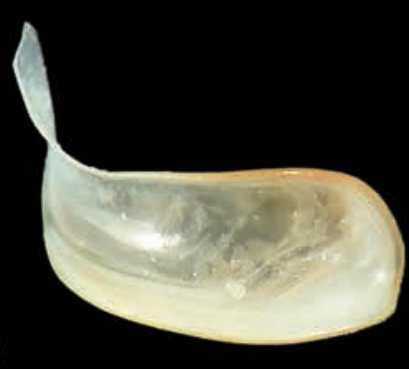

Figures 6-10. Parietum, palatum and clausilum of Albinaria (Albinaria) brevicollis astropalia, Astypalea Island, Greece. Fig. 6. Parietum: Astypalea, Livadhia; Fig. 7. Parietum: Astypalea, Vardhia, Fig. 8. Palatum: Astypalea, Konstantinos; Fig. 9. Palatum: Astypalea, Koutella, Fig. 10. Clausilium: Astypalea, Ftera. 


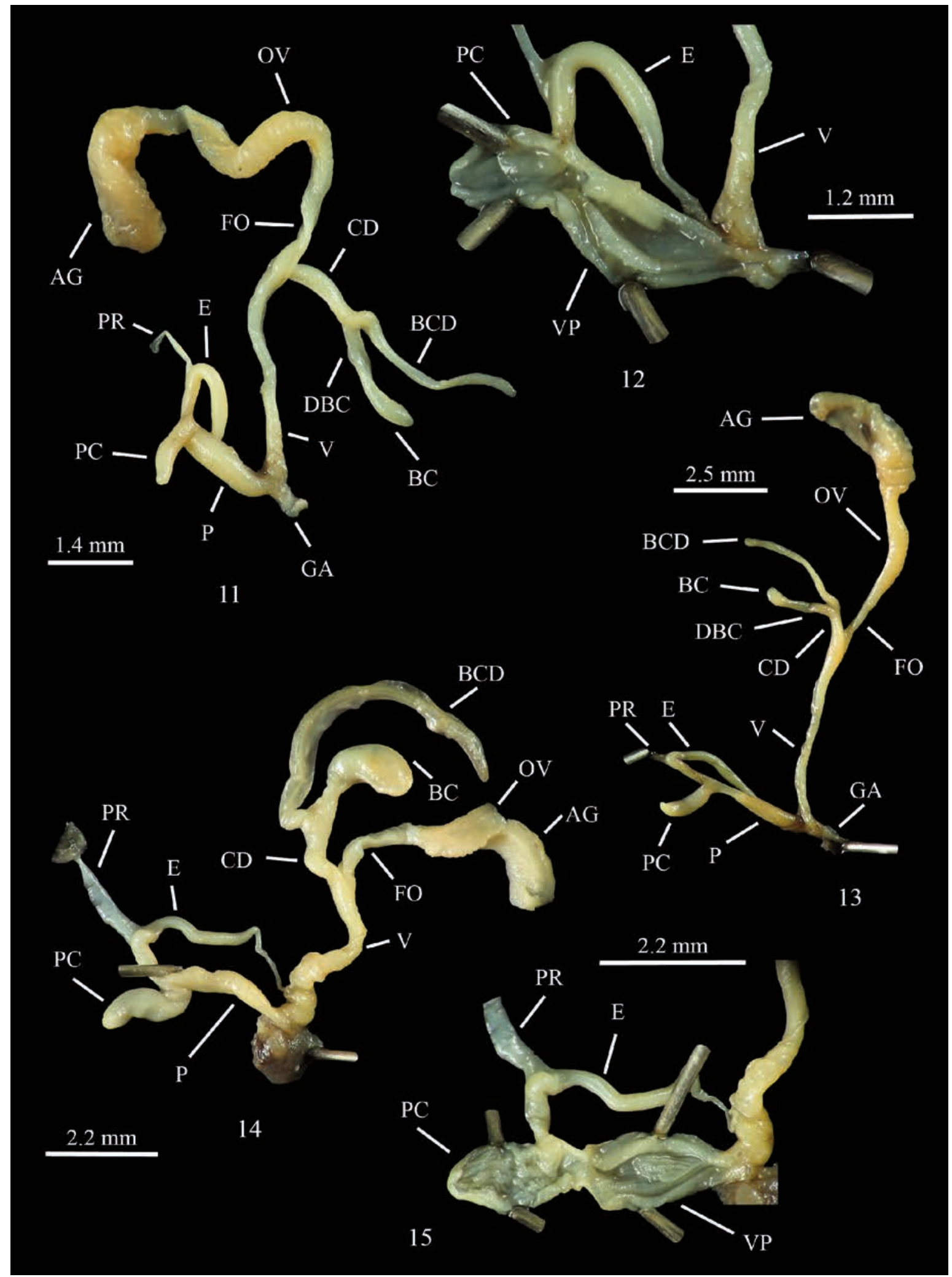

Figures 11-15. Genialia of Albinaria (Albinaria) brevicollis astropalia, Astypalea Island, Greece. Fig. 11. Genitalia: Ftera. Fig. 12. Internal structure of penis, same specimen of figure 11. Fig. 13. Genitalia: Konstantinos. Fig. 14. Genitalia: Livadhia. Fig. 15. Internal structure of penis, same specimen of figure 14. 


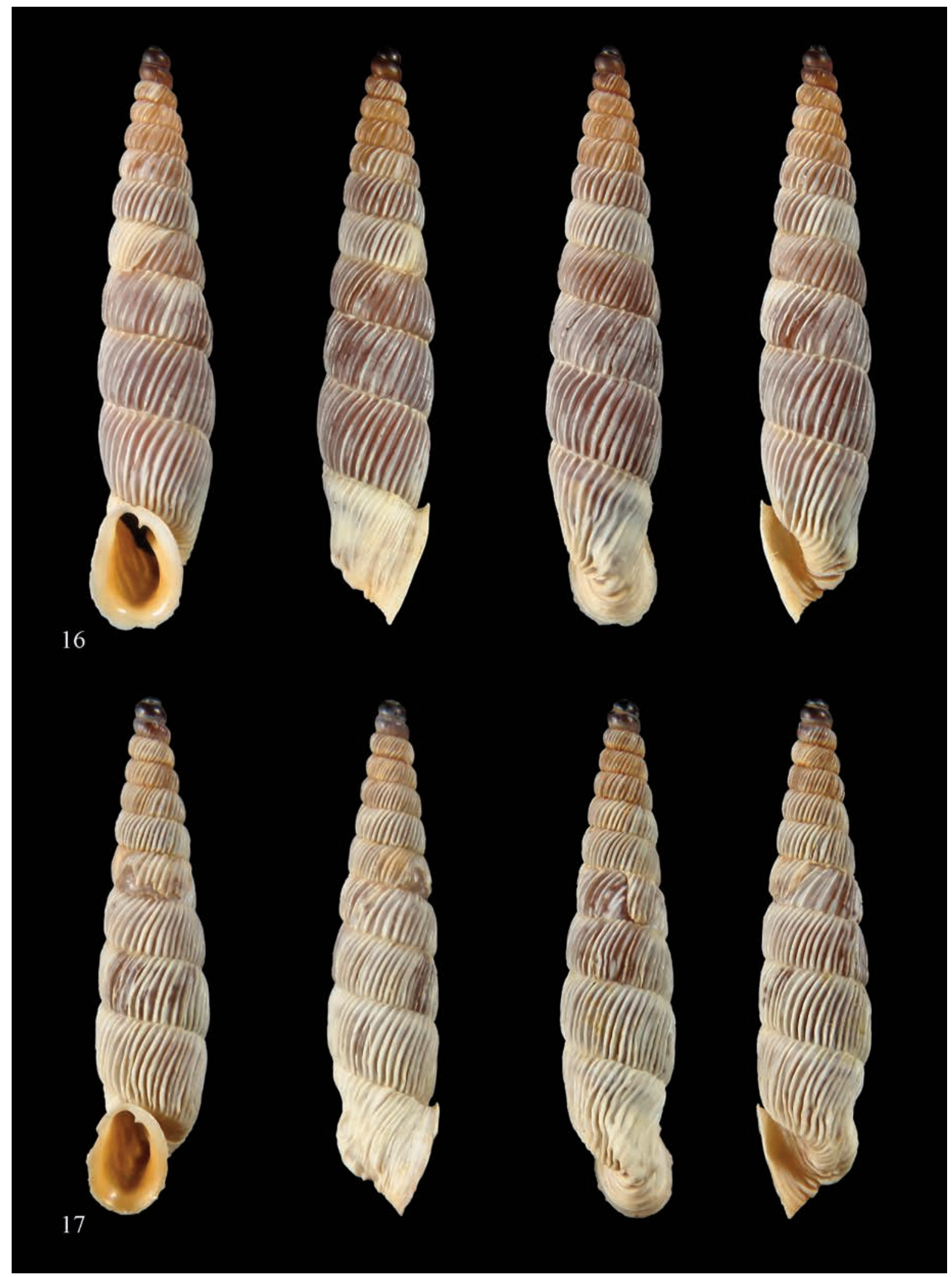

Fig. 16. Shell of Albinaria (Albinaria) brevicollis maltezana, Kounoupi Islet, islands group of Astypalea, Greece, H: $18.1 \mathrm{~mm}$, D: 3.6 mm. Fig. 17. idem, H: 14.9 mm, D: 3.3 mm. 


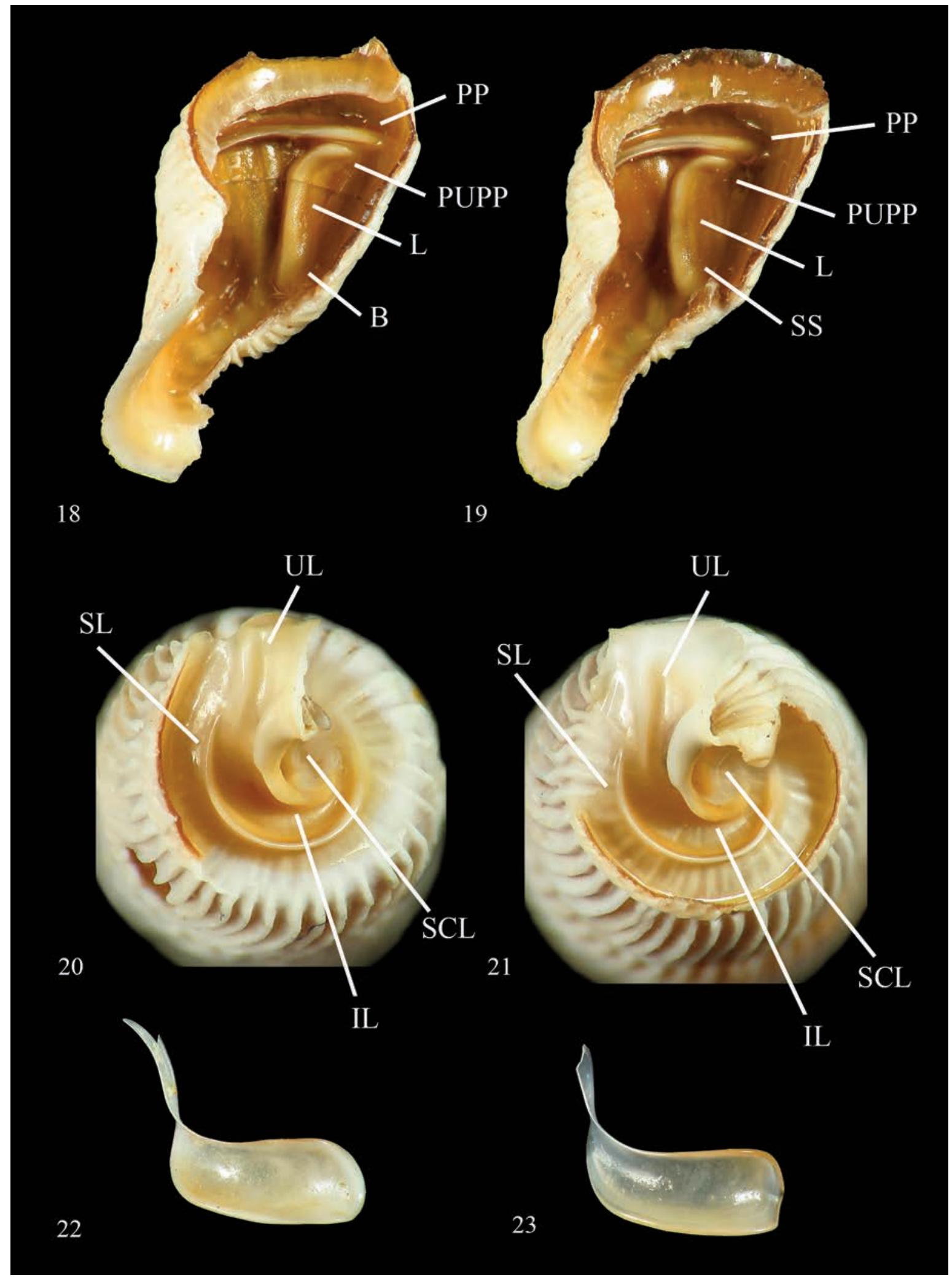

Figures 18-23. Parietum, palatum and clausilium of Albinaria (Albinaria) brevicollis maltezana, Kounoupi Islet, island group of Astypalea, Greece. Fig. 18. Parietum. Fig. 19. Parietum. Fig. 20. Palatum. Fig. 21. Palatum. Fig. 22. Clausilium, same specimen of figure 20. Fig. 23. Clausilium. 


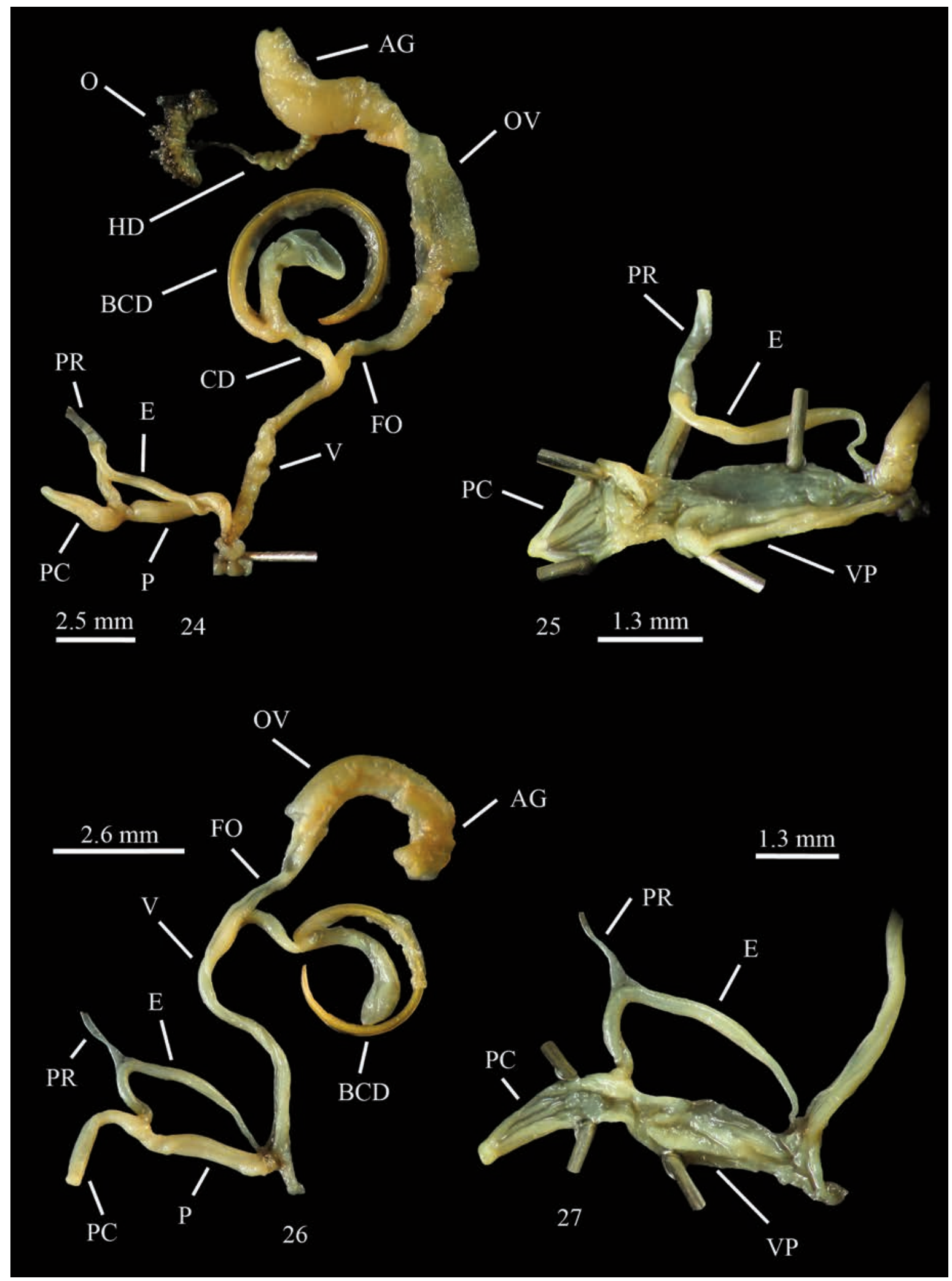

Figures 24-27. Genitalia of Albinaria (Albinaria) brevicollis maltezana, Konoupi Islet, islads group of Astypalea, Greece. Fig. 24. Genitalia. Fig. 25. Internal structure of penis, same specimen of figure 24. Fig. 26. Genitalia. Fig. 27. Internal structure of penis, same specimen of figure 26. 


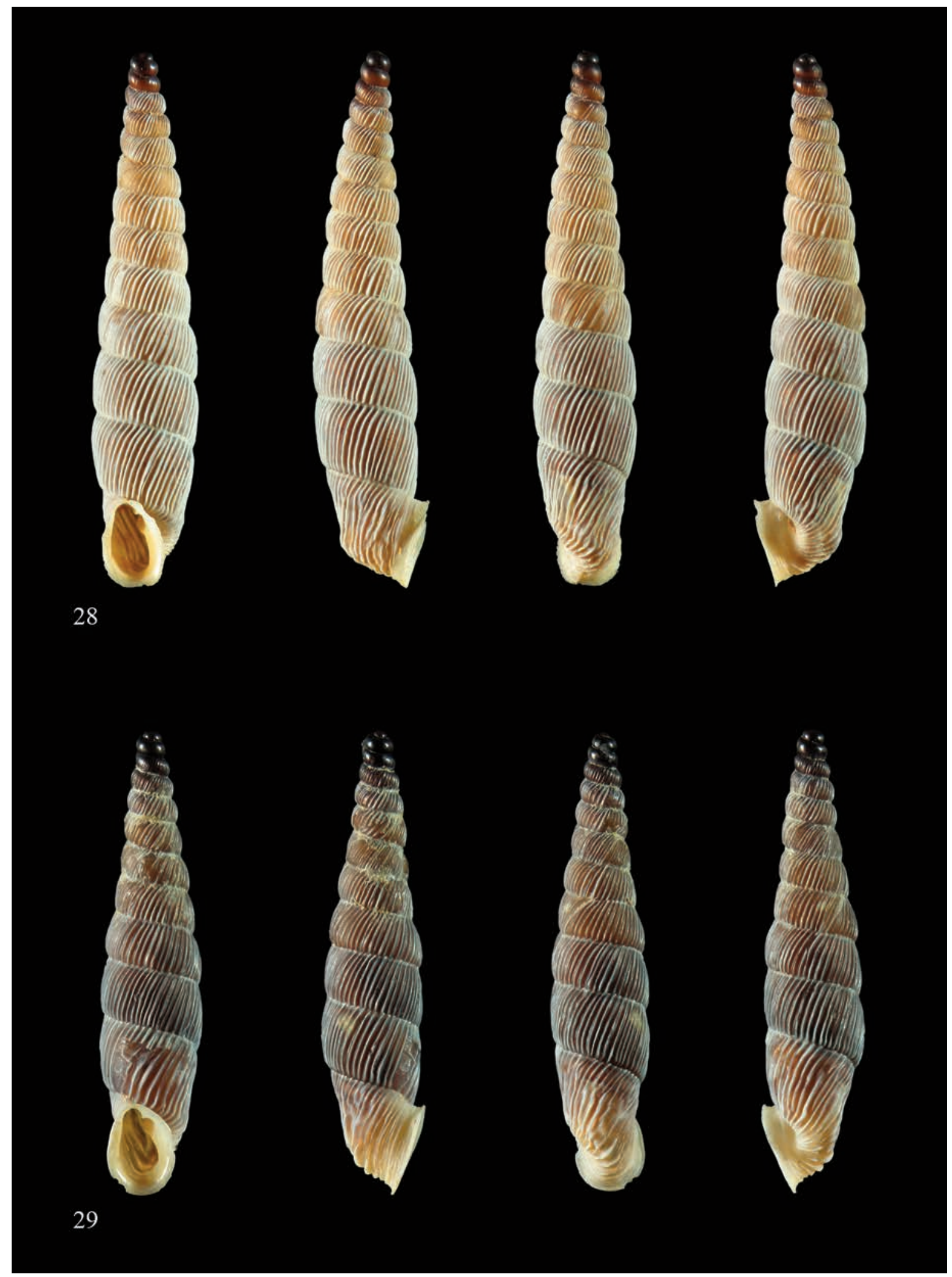

Fig. 28. Shell of Albinaria (Albinaria) brevicollis cf. sica, Dhragospilia, Astypalea Island, Greece, H: 15.2 mm, D: 3.2 mm. Fig. 29. idem, H: 16.45 mm, D: 3.15 mm. 

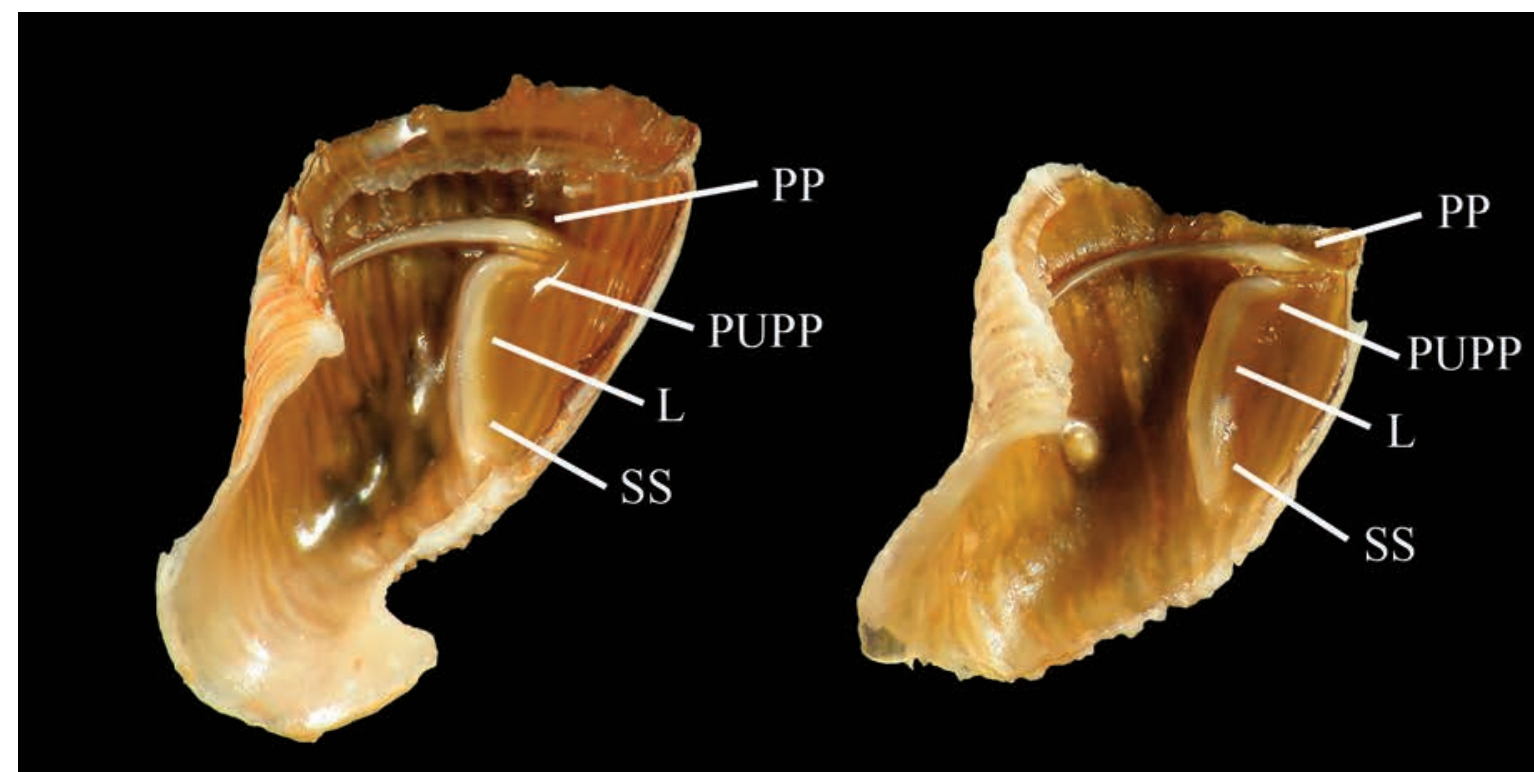

30

31
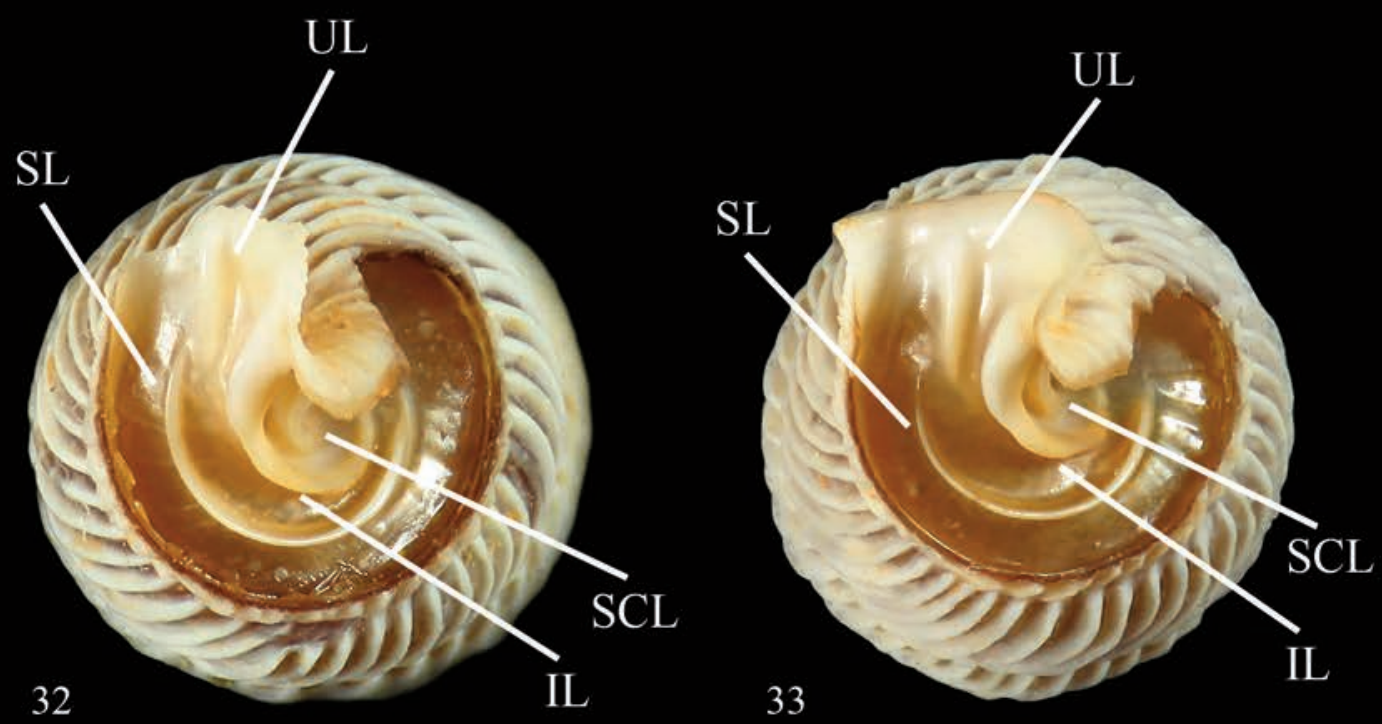

Figures 30-34. Parietum, Palatum and Clausilium of Albinaria (Albinaria) brevicollis cf. sica, Dhragospilia, Astypalea Island, Greece. Fig. 30. Parietum. Fig. 31. Parietum. Fig. 32. Palatum. Fig. 33. Palatum. Fig. 34. Clausilium, same specimen of figure 32 . 


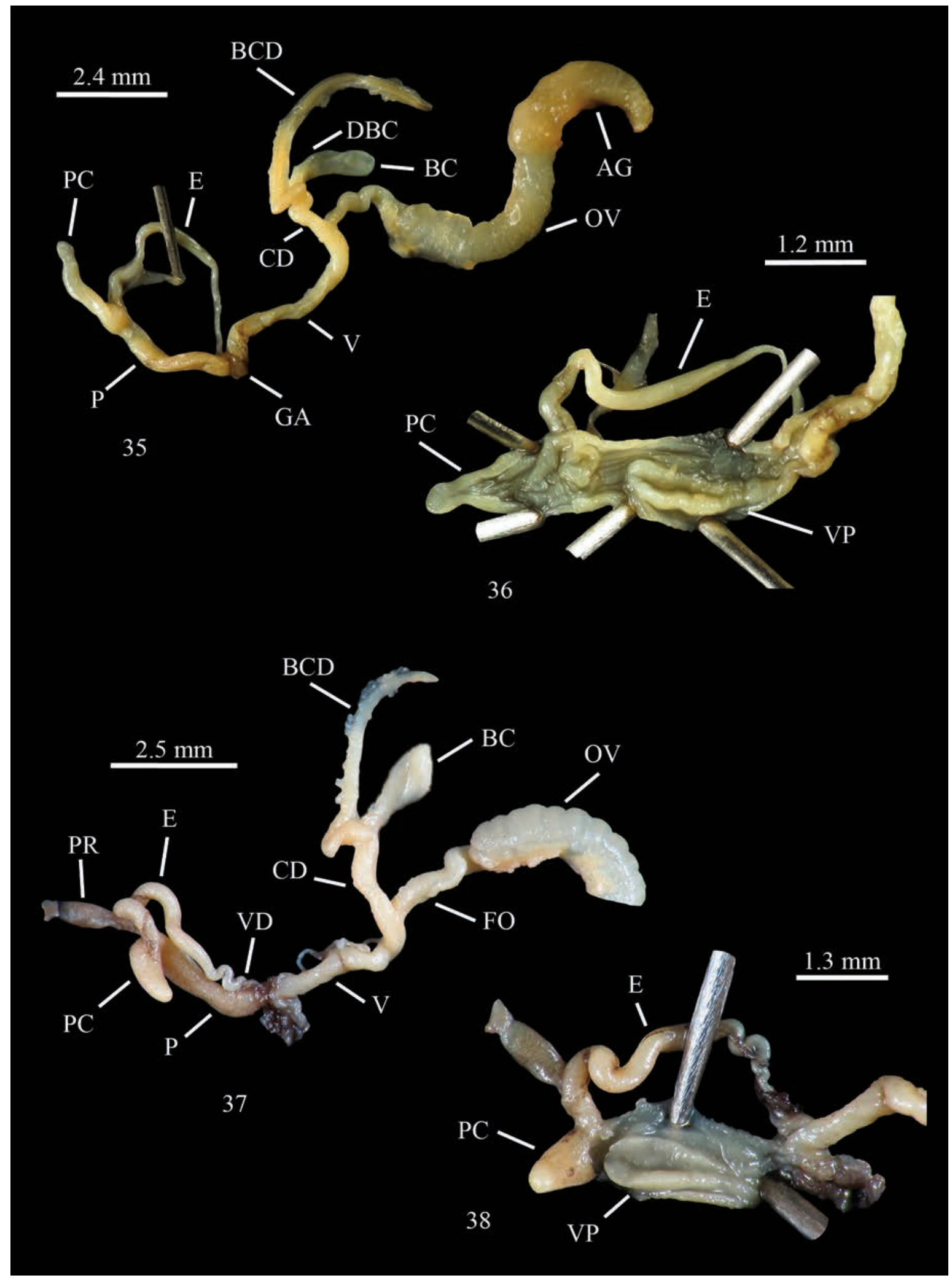

Figures 35-38. Genitalia of Albinaria (Albinaria) brevicollis cf. sica, Dhragospilia, Astypalea Island, Greece. Fig. 35. Genitalia. Fig. 36. Internal structure of penis, same specimen of figure 35. Fig. 37. Genitalia. Fig. 38. Internal structure of penis, same specimen of figure 37. 


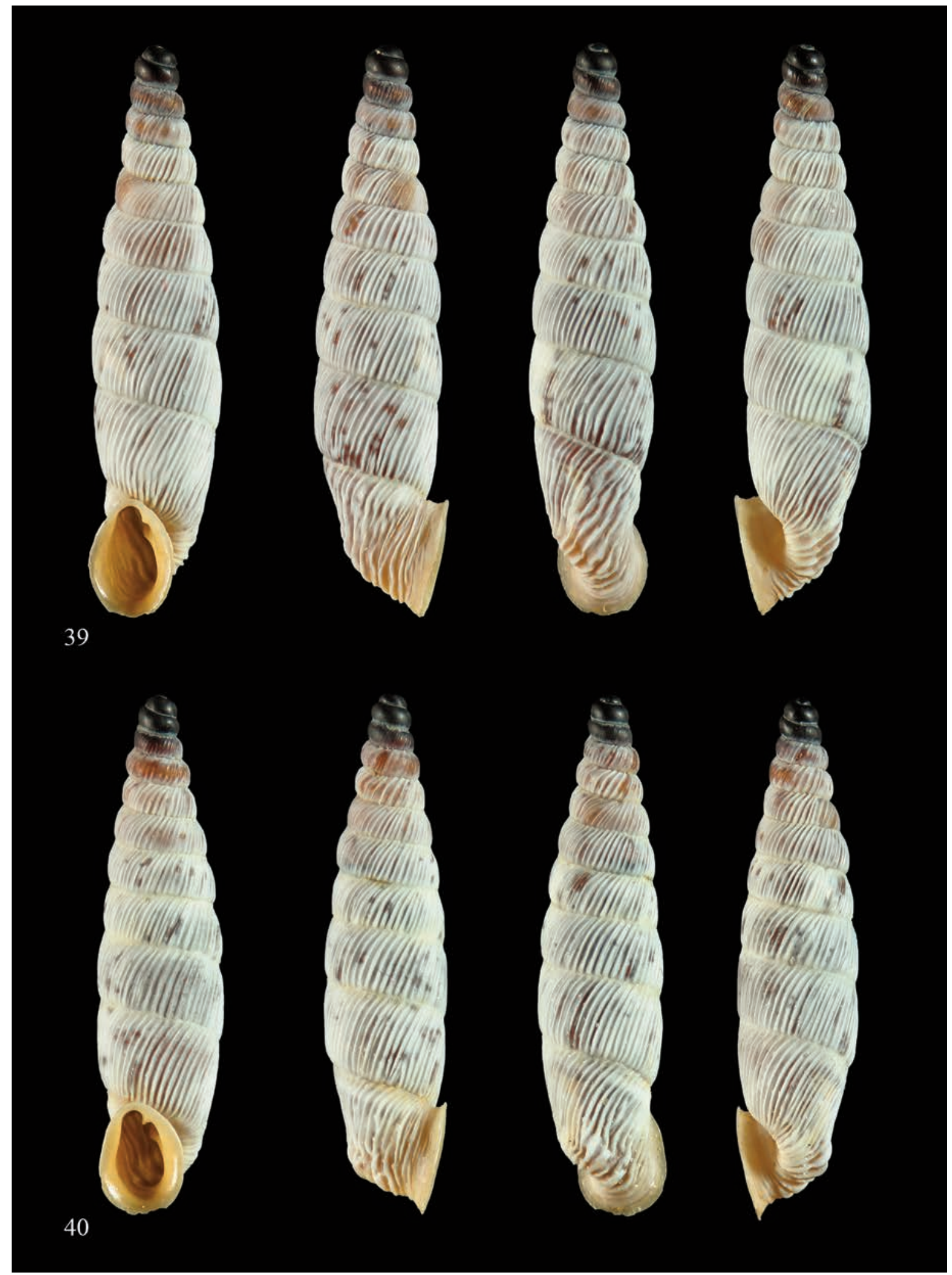

Fig. 39. Holotype of Albinaria (Albinaria) brevicollis granoi n. ssp., Pachia Ammos, Astypalea Island, Greece, H: 12.9 mm, D: 2.9 mm. Fig. 40. Paratype A. (A.) brevicollis granoi n. spp., idem, H: 12.7 mm, D: 3 mm. 


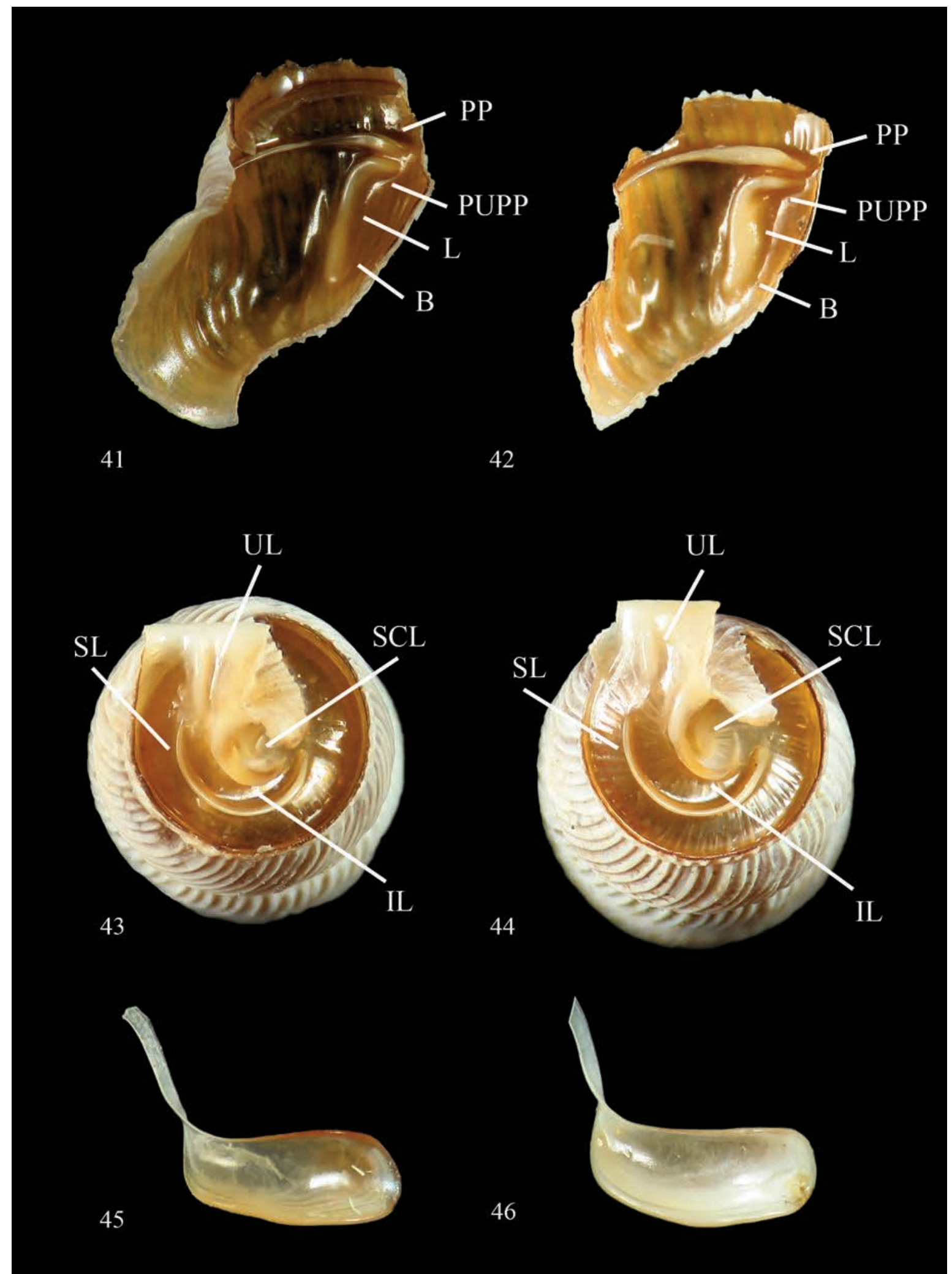

Figures 41-46. Parietum, palatum and clausilium of Albinaria (Albinaria) brevicollis granoi n. ssp., Pachia Ammos, Astypalea Island, Greece. Fig. 41. Parietum. Fig. 42. Parietum. Fig. 43. Palatum. Fig. 44. Palatum, same specimen of figure 42. Fig. 45. Clausilium. Fig. 46. Clausilium, same specimen of figure 44. 


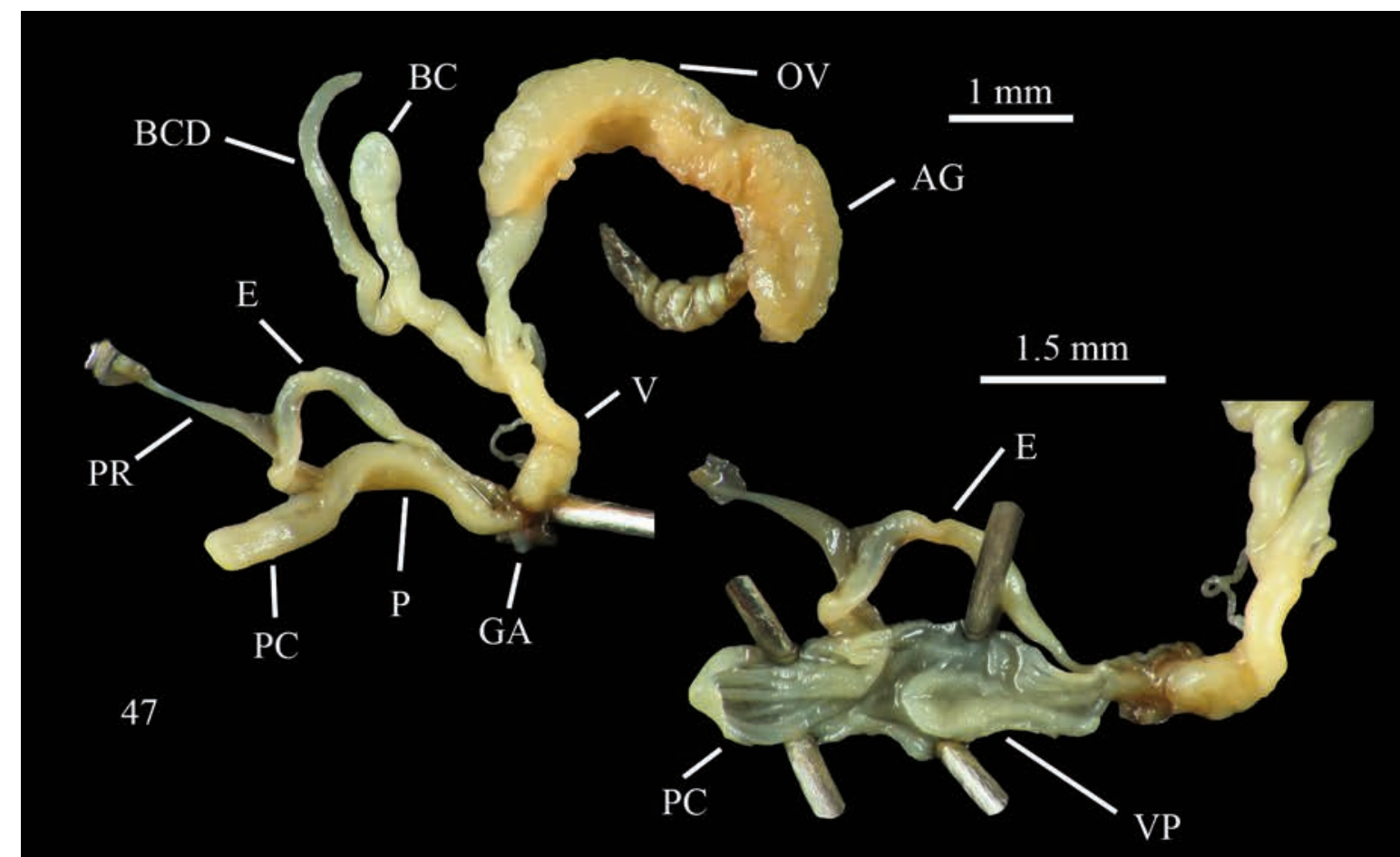

48

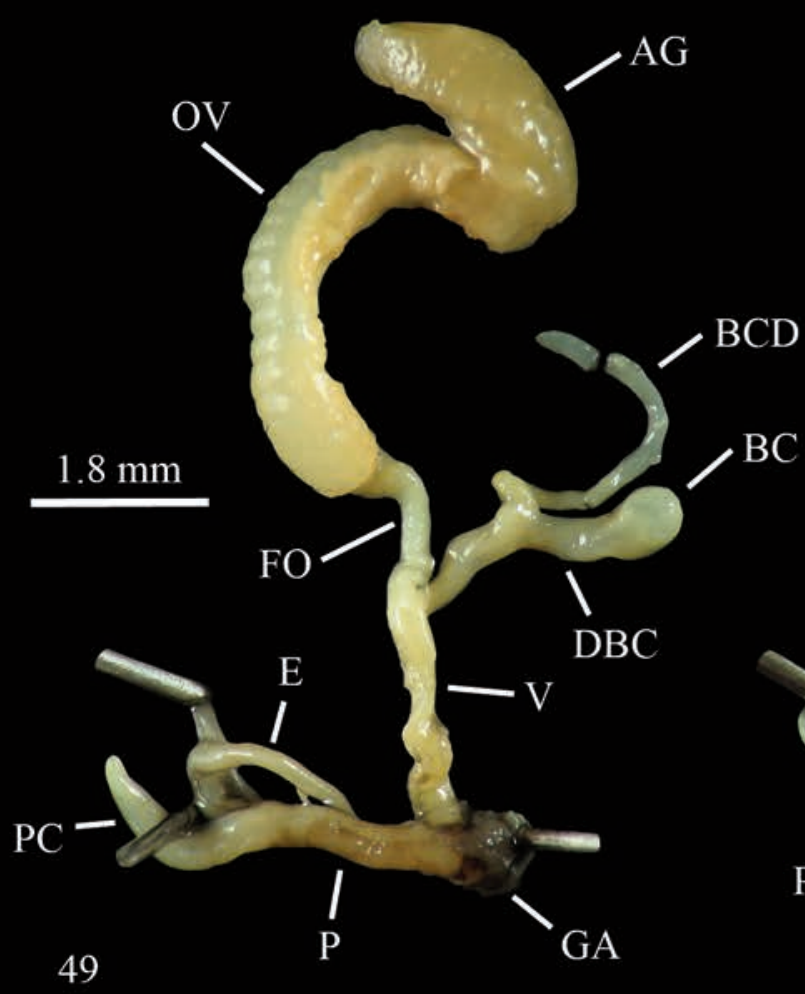

49

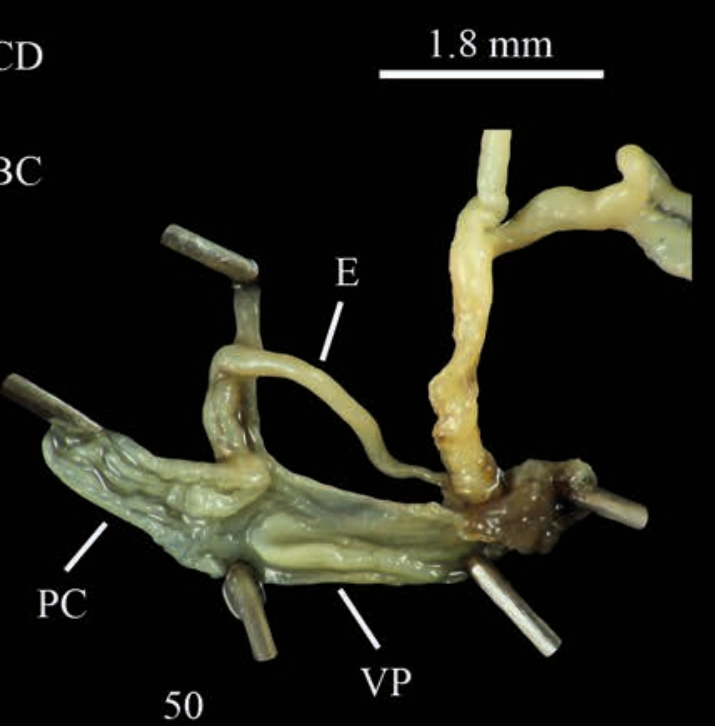

Figures 47-50. Genitalia of Albinaria (Albinaria) brevicollis granoi n. ssp., Pachia Ammos, Astypalea Island, Greece. Fig. 47. Genitalia. Fig. 48. Internal structure of penis, same specimen of figure 47. Fig. 49. Genitalia. Fig. 50. Internal structure of penis, same specimen of figure 49 . 


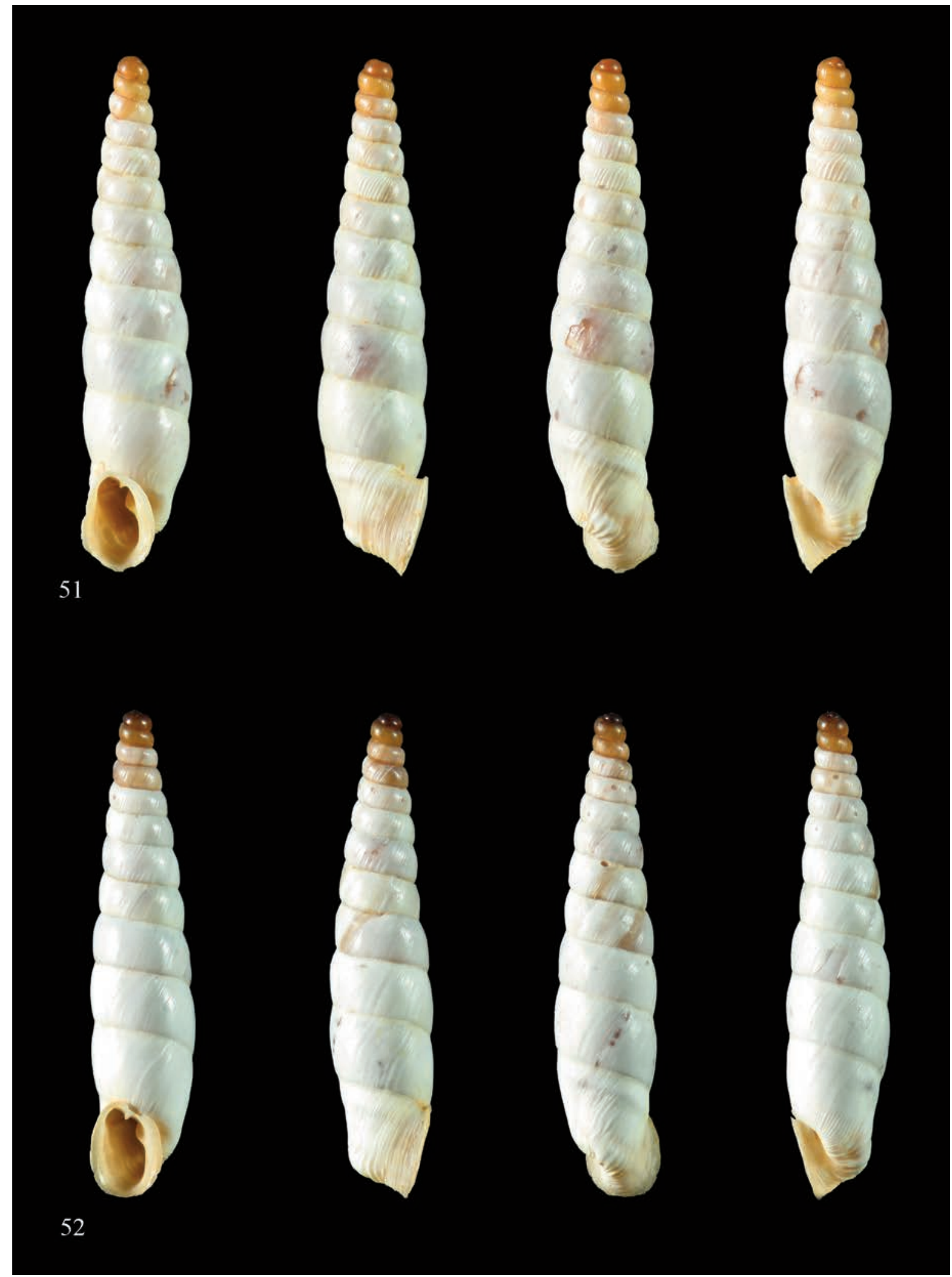

Figure 51. Holotype of Albinaria (Albinaria) brevicollis cristinae n. ssp., Ofidoussa Islet, islands group of Astypalea, Greece, H: 14.5 mm, D: 3.1 mm. Fig. 52. Paratype, A. (A.) brevicollis cristinae n. spp., idem, H: 14.7 mm, D: 3.1 mm. 
VARIABILITY. Height: 12.7-15 mm (mean 13.9 $\mathrm{mm}$ ), D: 2.8-3.1 mm (mean $2.9 \mathrm{~mm}$ ), whorls: 1011.75 (mean 10.5), R2 ( $=15)$ : 9-17 (mean 14). Dorsal keel about as high as basal keel or slightly stronger; upper lamella reaches or does not reach the spiral lamella; lower part of lunella with a rudiment of basalis (Figs. 40-44).

Dimensions of the genitalia (Figs. 47-50): P: $1.75 \mathrm{~mm}$, E: $2.6 \mathrm{~mm}, \mathrm{PC}: 1.7 \mathrm{~mm}$; vagina: 1.85 $\mathrm{mm}, \mathrm{CD} 1.25 \mathrm{~mm}, \mathrm{DBC}+\mathrm{BC} 1.46 \mathrm{~mm}, \mathrm{BCD}: 3.2$ $\mathrm{mm}$.

ETyMology. Named in honour of Mauro Grano (Rome, Italy), Italian herpetologist, who together with his colleague Cristina Cattaneo collected this new subspecies.

Distribution. Mountain ridge North-West Astypalea Island.

REMARKS. The smaller dimensions and the rounded and slender apical and subapical whorls differentiate this subspecies from the other ribbed subspecies A. (A.) brevicollis brevicollis from the Rhodes Island, A. (A.) brevicollis telensis K.L. Pfeiffer, 1955 from the Tilos island, A. brevicollis theodori K.L. Pfeiffer, 1955 from the island of San Theodoros. Finally, A. brevicollis granoi n. ssp. differs from A. brevicollis maltezana for the smaller dimensions, lower number of whorls, greater number of ribs and less developed dorsal keel and upper lamella.

\section{Albinaria (Albinaria) brevicollis cristinae n. ssp.}

TYPE LOCALITY. Ofidoussa Islet, west of Astypalea Island, Dodecanese Archipelago, Greece.

TYPE MATERIAL. Holotype (Fig. 51): Ofidoussa Islet, $36^{\circ} 33^{\prime} 12.38^{\prime \prime} \mathrm{N} \quad 26^{\circ} 08^{\prime} 23.29^{\prime \prime} \mathrm{E}, 82 \mathrm{~m}$, legit M. Grano and C. Cattaneo, 18.VIII.2015, (MCZRM-TYPE 00251/H). Paratypes: idem, 3 shs (CL 298-300; Fig. 52 shells CL 300).

DIAGNOSIS. Albinaria brevicollis cristinae n. ssp. is characterized by: slender, white shell; whorls convex and smooth; only on the last part of the last whorl there are thin and dense striae that reach the suture; dorsal keel prominent, upper lamella does not reach or reaches the spiral lamella.

DESCRIPTION OF THE HOLOTYPE (Fig. 51). Slender conical shell, only the last whorl tapering down- wards; H: $14.5 \mathrm{~mm}$, D: $3.1 \mathrm{~mm}$, with 2.5 apical whorl light brown, the other 9 whorls white with few brown spots; whorls convex and smooth, only the first three subapical whorls have weak striae and the last part of the last whorl shows very thin and dense striae that reach the suture; sutural bulge marked; basal keel distinct, dorsal keel stronger and shorter, convergent with basal; peristome detached; oval mouth, inside yellowish white. The upper lamella reaches the spiral lamella, the inferior lamella low, subcolumellar lamella not visible in oblique vision; lunella dorsal-dorsolateral in position; principal plica and posterior upper palatal plica ending dorsolaterally.

VARIABILITY. Height: 14-16.4 mm (mean 14.9 $\mathrm{mm}$ ), D: 2.75-3.1 mm (mean $3.0 \mathrm{~mm}$ ), whorls: 11.25-11.5; subapical whorls without striae in the three paratypes. The upper lamella does not reach (2 shs) or reaches the spiral lamella (2 shs); inferior lamella low or moderately high (Fig. 52).

Etymology. Named in honour of Cristina Cattaneo (Rome, Italy), Italian botanist and herpetologist, who together with her colleague Mauro Grano collected this new subspecies.

DistRIBUTION. Known only from type locality: Ofidoussa Islet.

REMARKS. Albinaria brevicollis cristinae $\mathrm{n}$. ssp. is somewhat similar to A. brevicollis heracleensis (O. Boettger, 1883) (Syn.: A. brevicollis karavica Fuchs \& Käufel, 1936) from the Karavi Nisa Islet (64 km southeast of Ofidoussa).

Albinaria brevicollis cristinae $\mathrm{n}$. ssp. is distinguished by A. brevicollis heracleesnsis for: the shorter and most prominent dorsal keel; the slightly more convex whorls, the thinner and more dense striae on the last part of the last whorl; more developed upper lamella (Boettger, 1883; Fuchs \& Käufel, 1936; K.L. Pfeiffer, 1955; Nordsieck, 1999).

\section{ACKNOWLEDGMENTS}

We are grateful to Hardmut Nordsieck (Forschungsinstitut, Frankfurt am Main, Germany) for helpful comments on the manuscript. 


\section{REFERENCES}

Bank R.A., 2017. Fauna Europaea project. Checklist of the land and freshwater Gastropoda of Europe, 167 pp.

Bank R., 2019. MolluscaBase. Albinaria Vest, 1867. Accessed at: http://molluscabase.org/aphia.php?p $=$ taxdetails\&id=996062 on 2019-12-12

Boettger O., 1883. On new Clausiliæ from the Levant, collected by Vice-Admiral T. Spratt R.N. Proceedings of the Zoological Society of London, 324-344, Pl. 33-34.

Douris V., Giokas S., Thomaz D., Lecanidou R. \& Rodakis G.C., 2007. Inference of evolutionary patterns of the land snail Albinaria in the Aegean archipelago: Is vicariance enough? Molecular Phylogenetics and Evolution, 44: 1224-1236.

Fuchs A. \& Käufel F., 1936. Anatomische und systematische Untersuchungen an Land- und Süßwasser-sch- necken aus Griechenland und von den Inseln des Ägäischen Meeres. Archiv für Naturgeschichte, Zeitschrift für systematische zoologie, 5: 541-662.

Nordsieck H., 1999. Annotated check-list of the species of the Albinaria-Isabellaria group (Gastropoda: Stylommatophora: Clausiliidae). Mitteilungen der Deutschen Malakozoologischen Gesellschaft, 62/63: 1-21.

Nordsieck H., 2015. New Species Taxa of Clausiliidae (Gastropoda, Stylommatophora) from the Balkan Peninsula and Turkey. Conchylia, 45: 3-26.

Pfeiffer K.L., 1955. Die Albinarien des Dodekanes (Moll.: Clausiliidae). Teil 1. Archiv für Molluskenkunde, 84: 109-153.

Ring U., 2001. Structure and deformation history of Astypalea island, Aegean Sea. Bulletin of the Geological Society of Greece, 34: 329-335. http://dx.doi.org/10.12681/bgsg.17030

Terrain Cartography Group., 2009. Astypalea Terrain Map, 330 (scale: 1:25.000). 